\title{
IAMJ
}

INTERNATIONAL

AYURVEDIC

MEDICAL JOURNAL

\section{AYURVEDIC MANAGEMENT OF AMLAPITTA (GASTRITIS) - A CASE REPORT}

\section{Divya Singh Charan ${ }^{1}$, Pramod Kumar Mishra², Indu Sharma ${ }^{3}$, Neha Grover ${ }^{4}$}

${ }^{1}$ MD Scholar P.G. Department of Kayachikitsa,

${ }^{2}$ Professor and HOD, P.G. Department of Kayachikitsa, University College of Ayurveda, Dr. Sarvepalli

Radhakrishnan Rajasthan, Ayurved University Jodhpur, Rajasthan, India

${ }^{3}$ Associate Professor P.G. Department of Kayachikitsa, Govt. Ayurvedic College of Udaipur, Rajasthan, India ${ }^{4}$ MD Scholar P.G. Department of Kayachikitsa,

\section{Corresponding Author: divyacharan.dr@gmail.com}

\section{https://doi.org/10.46607/iamj5209102021}

(Published Online: October 2021)

Open Access

(C) International Ayurvedic Medical Journal, India 2021

Article Received: 17/09//2021 - Peer Reviewed: 05/10/2021 - Accepted for Publication: 06/10/2021

\section{Check for updates}

\begin{abstract}
Amlapitta is the most typical illness in the present era. In a rapidly growing civilization, Amlapitta is the outermost common disorder within the current society, because of indulgence in incompatible food habits and activities. Materialistic lifestyle provokes people to run behind a busy, tremendous stressful life which is the least concern towards proper food habits. "Hurry", "Worry" \& "Curry" are the main causes of Amlapitta disease. The usage of synthetic drugs like $\mathrm{H}^{2}$ receptor blockers \& proton pump inhibitors has decreased due to their side effects. The signs and symptoms of Amlapitta are very comparable to Gastritis or Hyperacidity. The ruling features of Amlapitta are Avipaka (indigestion), Urodaha (Burning in the chest), Utklesha (Nausea) Aruchi (Anorexia) and Tikta-Amlodgara (sour and bitter belching) have been described in Ayurvedic classical texts. A 42-year-old male patient came in OPD with the following complaints Tikta-Amlodgara, Urodaha, Utklesha, Aruchi, Praseka. During Examination, the vitals are normal. The patient was treated with Sutshekar rasa 1 tab. BD, Avipattikar churana $3 \mathrm{gm} \mathrm{BD}$, Drakshavaleha $5 \mathrm{gm} \mathrm{BD}$ on the basis. The patient was advised to follow up every $15^{\text {th }}$ day. Along with medication, the patient was also advised to follow diet and lifestyle restrictions.
\end{abstract}


Keywords: Agni, Amlapitta, Annavahasrotas, Hyperacidity.

\section{INTRODUCTION}

Amlapitta is a prevalent functional disease of Annavaha Srotas caused by vitiated Agni (appetite). Incongruous and unwholesome dietary habits cause Dushti of Annavaha Strotas which routes to numerous disorders and Amlapitta is one of them. The "Amlapitta" (Hyperacidity) is possessed by words'Amla' (Sour) in addition to 'Pitta' (Gastric Juice). Pitta Vardhaka Ahar Vihar is that the only reason for Amlapitta. In Amlapitta (Hyperacidity) the quantity of Pachaka Pitta (Gastric juice) is incremented; its quality of mundane acrid taste (alkaline) is modified to a surplus of sour taste (acidic) because of fermentation. The stimulating factors are dreadful stress \& solicitousness which consequently instigate the Amlapitta(hyperacidity). Amlapitta is a disease that occurs due to perturbation of certain guna of Pitta like Drava (fluidity) and Amla guna (sourness) which result in Vidagdhajirna (indigestion caused due to acidified chyle) at the initial stages and later causes exasperation and corrosion of the "Sleshmadhara Kala" of the "Amashaya. the mucous membrane of the stomach and duodenum. Amlapitta(hyperacidity) possesses the characteristic of co-cognate at a local location relative to hyperacidity (gastritis) as modern science is concerned. Gastritis is inflammation of gastric mucosa. In Brihatrayees of Ayurveda, scattered references are available about Amlapitta. Amlapitta disease has been explicated in Kashyapa Samhita. Madhava nidana, Bhavaprakasha in addition to Yoga Ratnakar, Chakradutt has additionally narrated it. Vagbhata has described that all diseases are caused because of Mandagni. The surplus proximate conditions have been mentioned in Ayurveda texts like Charaka Samhita, Sushruta Samhita and Vagbhata Samhita while describing the Grahani roga and Vidagdhajirna. The primary Samhita which gives a detailed elucidation of the disease together with its etiopathogenesis, manifestation with its therapeutics compact that is Kashyapa Samhita. Two types of the Amlapitta are described in Ayurvedic texts, i.e., Urdhwaga and Adhoga Amlapitta. In Urdhwaga Am- lapitta vitiated Pitta and Kapha are the key factors for the pathology. Inordinate consumption of Amla, Katu, Ushna and Vidahiaharsevana and Viruddhashana, spicy, sour, salty substance, oily and cumbersomely hefty to digest aliments causes elicitation of Pitta dosha. Customarily Pitta has Katu rasa but when Katu rasa is transformed into Amla rasa, it causes Amlapitta. According to modern medical science, the prevalent causes possessed by gastritis are H. pylori infections and longer utilization of NonSteroidal Anti-Inflammatory Drugs (NSAIDS), Aspirin and Other drugs, e.g., iron preparations, Severe physiological stress, e.g., burns, multi-organ failure, central nervous system trauma and Autoimmunity.

\section{Case Report:}

A 42-year-old male patient came in OPD with the following symptoms,

- Tikta-Amlodgara (eructation with bitter and sour taste)

- Urodaha (Burning in the chest)

- Utklesha (Nausea)

- Aruchi (Anorexia)

- Praseka (Excessive salivation)

\section{History of Patient}

History of present illness: He had a history of above all symptoms for two to three years. He was suffering from Amlapitta for two to three years. He didn't get relief after taking treatment at many places. Complaints were Tikta Amlodgara $(+++)$, Urodaha $(++++)$, Aruchi $(+++)$, Utklesha $(+++)$. His symptoms were on and off, and present almost five days per week since last year. Due to their farming occupation, he was having irregular sleeping and lunch/dinner times.

History: No major illness.

Family History: NAD.

- Examination of the patient:

Ashtavidha Pareeksha

Nadi (Pulse): Pitta Pradhan, Vatanuubandhi.

Mala (Stool): Apakva, Asamyaka, Guda daha (occasional), Baddha koshtha (occasional). 
Mutra (Urine): Samyak Mutrapravartana

Shabda (Speech): Prakrut

Bala: Madhyam

Sparsh (Skin): Snigdha, Mrudu

Druk (Eyes): Prakruta

Akruti: Mandya

Jivha (Tongue): Sama(coated), Aruchi, Mukhapaka (occasional).

Diagnosis - Amlapitta.

- General examination

Pulse: 78/min.

RS: normal
BP: 122/86 $\mathrm{mm}$ of $\mathrm{Hg}$.

Agni: Mandagni, Abhyavaharan shakti decreased, Jara-na Shakti decreased.

Koshtha: Krura.

Prakruti: Pitta pradhana-vata.

Udara pariskha: Adhmana, Udara kathinya.

- Nidan panchaka:

* Hetu

- Ahara - Aniyamita ahara, Atiamla Aahara, Atikatu Aahar (spicy), Adhyashan etc.

- Vihara-Jagran, Diwaswap.

\section{Samprapti:}

Nidan sevana

$\sqrt{1}$

Aggravated vatadi doshas

Mandagni

II

Shukta (food remains in abdomen due to improper burning)

$\sqrt{1}$

Annavisha

I

Amadosha

II

Amlapitta

\section{- Samprapti Ghataka:}

Dosha: Pitta pradhana, Kapha anubandhi

Dushya: Rasa dushti.

Strotodushti: Annavaha, Purishvaha, Rasavaha.

Vyadhi avastha: Sama avastha, Kapha utkelsha,

Dosha urdhwa gati.

Sadhyasadhyatva: Kashta sadhya.
Vyadhi marga: Abhyantar.

- Vyadhi Nidana (Diagnostic Criteria):

Burning sensation in the chest (Urodaha), Eructation with a bitter and sour taste (Tikta-amlodgar), Nausea (Utklesha), Indigestion (Avipaka), Loss of appetite (Aruchi) and Exertion without work (klama) these are cardinal symptoms of Amlapitta.

\section{Therapeutic Intervention:}

\begin{tabular}{|l|l|l|l|}
\hline S. No & Name of Drug & Dose & Frequency and Anupana \\
\hline 1. & Sutshekar rasa & 1tab. after meals & Twice a day with Madhu. \\
\hline 2. & Avipattikar churana & 3grams after meals & Twice a day with lukewarm water. \\
\hline 3. & Drakshavaleha & 5grams after meals & Twice a day with milk. \\
\hline
\end{tabular}




\section{Formulation of Intervention Medicine: -}

\begin{tabular}{|c|c|c|c|}
\hline S.no & $\begin{array}{l}\text { Ayurvedic } \\
\text { Medicine }\end{array}$ & Ingredients & References \\
\hline 1. & Sutshekar rasa & $\begin{array}{l}\text { Sodhita Parad (Purified Mercury), Sodhita Gandhak (Purified Sulphur), Sodhita } \\
\text { Makshik (Chalcopyrite), Shankh bhasam (Conch shell), Tamra bhasam(Copper), } \\
\text { Tankan (Borax), Sodhit Vatasnava (Purified Aconitum Ferox), Sodhit Dhatura } \\
\text { (Purified Dhatura metal), Shunthi (Zingiber officinale), Maricha (piper nigram), } \\
\text { Pippali (piper longum), Twak (Cinnamomum zeylanicum), Patra (Cinnamomum } \\
\text { tamala), Ela (Elettaria cardamomum), Nagakeshar(Messua ferrae), Bilwamaj- } \\
\text { ja(Aegles marmelos) and Bhringraj swarasa(Eclipta alba)(bhavana). }\end{array}$ & $\begin{array}{l}\text { Yog Ratnakar } \\
\text { (AFI-2) }\end{array}$ \\
\hline 2. & $\begin{array}{l}\text { Avipattikar } \\
\text { churana }\end{array}$ & $\begin{array}{l}\text { Shunthi (Zingiber officinale), Maricha (piper nigram), Pippali (piper longum), } \\
\text { Haritaki (Terminalia chebula), Vibhitaki (Terminalia bellirica), Amalaki (Embel- } \\
\text { ica officinalis), Mustaka (Cyperus rotundus), Vida lavana, Vidanga ((Embelica } \\
\text { ribes), Ela (Eletaria cardamomum), Twak (Cinnamomum zeylanicum), Lavang } \\
\text { (Syzgium aromaticm), Trivrit (Operculina terpethum) and Sharkara (Saccharum } \\
\text { officinarum). }\end{array}$ & $\begin{array}{l}\text { Bhaishajya } \\
\text { Ratnavali, Am- } \\
\text { lapitta 25-29 }\end{array}$ \\
\hline 3. & Drakshavaleha & $\begin{array}{l}\text { Draksha (Vitis venifera), Kana (Piper longum), Yestimadhu (Glycyrrhia glabra), } \\
\text { Vamshalochana (Bambusa arundinacea), Dhatri phala (Embilica officinalis). }\end{array}$ & \\
\hline
\end{tabular}

Along with medication, diet and lifestyle restrictions were also advised to the patient. Patients were asked to follow the mealtimes and to take light food, coconut water, articles having cooling properties, vegetables like white pumpkin, bitter ground, cucumber, fruits like gooseberry, black grapes, fig, dry grapes., an adequate number of fluids like amla juice, pomegranate juice, warm water, take adequate sleep or rest. With this treatment, the patient was asked not to take Amla, Lavana, Katu, Vidahiaharsevana and Viruddhashana. Avoid excessive spicy, sour, salty substances, oily and heavy to digest and junk food items.

- Follow-up: The patient was followed up once on the $15^{\text {th }}$ day up to the 45 days. During first follow up there was mild relief in Tikta-amlodgar, Urodaha, Utklesha and Praseka. The patient was advised to continue the same medication. During $2^{\text {nd }}$ follow up Tikta-amlodgar, Urodaha, Utklesha and Praseka completely gone and there is mild relief in Aruchi. During $3^{\text {rd }}$ follow up no other complaints were told by the patient. The patient was advised to follow the diet and lifestyle restrictions. Avoid lying down immediately after food and in the supine position. Avoid smoking, alcohol, tea, coffee, and stress.
Mode of action Sutshekar rasa: Most of drugs of Sutshekar rasa are Tikta kasaya and Madhur rasa dominant properties.

- Tikta and kasaya rasa subside Kapha Doshas.

- Pippali is the best Ama Pachana.

- Sankha Bhasma and Tankan both have Kshariya nature neutralize the acidity and maintains acidbase balance in the stomach.

- Tamra bhasam is also mentioned as amlapittnashak.

$>$ Mode of Action Avipattikar churana: these drugs are commonly Deepniye, Pachniye, Agnivardhaka and reduce the symptoms of vitiated Pitta, Ama, vitiated Samana and Udana vayu which will help in digestion of Ama for the Shaman of raised Pitta. Avipattikar churna has purgative action thus used in Shodhana of vitiated Pitta in Amlapitta.

Mode of Action Drakshavaleha: Drakshavaleha has anti-anaemic properties and nutritional properties. It has been used as a Naimittika Rasayana (promoter of specific vitality in specific disease an Amlapitta is one of them). 


\section{DISCUSSION}

Amlapitta has become a very common problem in the present scenario; it is due to unhealthy food habits and regimens. The incompatible diet, regimen and habits continued, it may lead to gastric ulcer, chronic gastritis, duodenitis, irritable bowel syndrome, malabsorption, anaemia, and stenosis. As in disease, Amlapitta vitiated dravya roop of Pitta is a primarily responsible factor and changes in the function of agni (appetite) lead to various diseases. It is common for many of us to face a burning sensation in the stomach and chest. All the drugs utilized in the study were Pitta shamak which mitigate the Pitta dosha and Kapha stabilize. Most of the medication (in samana aspects are having Tikta rasa which has Vayu+ Akasha Mahabhuta. The Vayu Mahabhuta dries up the Dravtva of Dushita Pitta and this Akasha Mahabhuta removes the Srotorodha during a Samprapti Vighatana. These drugs work on subjective symptoms and physical, mental, emotional health.

\section{RESULT}

Amlapitta shows complete resolution at the end of 45 days. Oral remedies "Shutshekar rasa" "Avipattikar churana" "Drakshavaleha" is effective for the above symptoms.

\section{CONCLUSION}

"Sutshekar rasa"-the vitiated state of pitta improves the whole digestion process and result in the proper functioning of Agni. Sutshekar rasa having properties like ruksha, laghu, katu\& ushan has an effect to decrease the vitiated pitta and maintain the proper functioning of Agni. Sutshekhar rasa has ingredients which are mainly agnivardhak \& amapachak properties. "Avipattikar churana"- a more potent drug in the treatment of Amlapitta without any side effect. In this churana the drug is madhur tikta kasaya, katu rasa yukta and Madhur vipaka and Sitavirya. In Amlapitta, vidagada pitta is neutralized by the ingredients of Avipattikar churna.

\section{REFERENCES}

1. Madhavakara Madhavanidana - Part II Madhukosha Sanskrit comm. By Shri VijayRakashit and Shri Kan- tha Dutta AmlapittaAdhayaya 21st edition. Published by Chaukamba Sanskrit sansthana, Varanasi 1993.

2. Madhavakara Madhavanidana- Vidhyotinihindi Comm. By Shri SudarshanShastri, AmlapittaAdhayaya 21 st edi. Published by Chaukamba Sanskrit sansthana, Varanasi 1993, Pg No. 170-172.

3. Charaka Samhita - By Dr Bramhanand Tripathi, chikitsasthana, Grahani Adhyaya, 15/45-47, chaukhamba prakashana1988.

4. Sushruta Samhita - Dr. Anantarama Sharma ed. Sushruta Samhita of Sushruta vol.-1, sutra 46/502, reprint ed. 2008, Chaukhambha Surabharati Prakashana, Varanasi.

5. Ashtangahrudaya - Sarvangsundartika, By Vd. P.V. Sharma, sutrasthan 8/26, 8th edition, 1998, chaukhmba prakashan, Varanasi.

6. Kaspyapa Samhita or Vrddha Jivaka revised by Vatsya with Sanskrit Introduction by Nepal Rajgura Pandit Hemraja Sharma with Vidhyotini Hindi commentary, Chaukhamba Sanskrit series office Khil Sthana, Chapter 16. Verse 1-14 Edi. Reprint, 2008; 335.

7. Bhavaprakasa of Sri Bhavamisra edited with Vidhyotini Hindi commentary by Bhisagratna Pandit Sri Brahma Shankar Mishra, Jaya krishan Das Haridas Gupta Chaukhamba Sanskrit Series Office. Chapter 10. Verse 20-22 Edi. Reprint, 2008; 298.

8. Chakradatta of Sri Chakra- panidata with the Vaidyaprabha Hindi Commentary and Notes Introduction by Dr Indradeva Tripathi, Edited prof. Ramanath Dwivedy, Chaukhamba Sanskrit Bhawan, Varanasi Edition, Reprint, 2011; 52: 295.

9. Chrak samhita chikitsaasthana Vol- 2nd, Prof priyavrat Sharma Chaukhamba Sanskrit sansthan Varanasi 7th Edition, 2003; 249.

10. Bharat Bhaishajya Ratnakara - 5/8261. / Bharat Bhaishajya Ratnakara - 3/4468.

11. Yogratnakara, Amlapittadhikara.

12. Markad UB, Shinde BT. To evaluate the efficacy of Dhanyakadi churna in the management of Amlapitta A Case Study. International Journal of Research in Ayurveda and Medical Sciences 2019.

13. Nibedita, M., Debasis, B., Seema Krishna, M., Vishnu Dutt, S., \& Siddaram, *Arawatti. (2016). A CLINICAL STUDY ON AMLAPITTA AND ITS MANAGEMENT WITHCHHINNODBHAVADI GHANAVATI. International Journal of Ayurveda and Pharma Research.

14. Dr Santosh Achutrao Chate Professor- Ayurvedic Management of Urdhwaga Amlapitta: A Case Report 
(2019) Aayushi International Interdisciplinary Research Journal (AIIRJ).

15. Hanumanthu Kishore Kumar, C. H. Sridurga, and Dabbu Bhaskar Rao- Clinical efficacy of Baladi Manduram in the management of Amlapitta 2018.

\section{Source of Support: Nil}

\section{Conflict of Interest: None Declared}

How to cite this URL: Divya Singh Charan et al: Ayurvedic Management of Amlapitta (Gastritis) - $\mathcal{A}$ Case Report. International Ayurvedic Medical Journal \{online\} 2021 \{cited October 2021\} Available from: http://www.iamj.in/posts/images/upload/2609_2614.pdf 